As mentioned earlier, the work of the Museum is by no means limited to the collection of the objects themselves. Every attempt is made to obtain accounts of how processes or operations were carried out. These are sometimes provided by people who themselves remember them, or by the Museum's own staff or collaborators interviewing members of the older generation who can provide useful information. It is intended in the future to expand this work considerably. Already an attempt is being made to photograph sequences of crafts or farm tasks that are becoming rare, and eventually it is hoped to record some of these by making short record-films. It is hoped, too, to prepare questionnaires on certain subjects and to enlist the aid of local historians in compiling them. All these tasks will serve to make the exhibits themselves more useful and to provide a more adequate background to the subject.

The speed with which the Museum has become known is very gratifying. Already it is beginning to be used by many people, and it is clear that the belief of its founders in the need for a specialist museum of this type is amply justified. It is still, however, after four years, at the very beginning of the road; a great deal remains to be done before it can achieve fully the aims which it has set itself. If, however, it continues to receive the enthusiasm and support and assistance which it has met on all sides, its future is assured.

\section{INTERNATIONAL CONFERENCE ON MARINE BIOLOGICAL LABORATORIES}

$\mathrm{F}^{\mathrm{o}}$ OLLOWING a decision of the Bureau of the International Union of Biological Sciences, an International Conference on Marine Biological Laboratories was held in Rome during April 18-22, immediately after the meeting of the General Assembly of the International Union. The Committee appointed to take charge of the organization of the Conference consisted of Prof. Robert W. Hiatt (University of Hawaii) as chairman, with Prof. J. Runnström (University of Stockholm) and Prof. C. M. Yonge (University of Glasgow) as members. The Conference was attended by official participants from Canada, Denmark, Egypt, France, Germany, Great Britain, Italy, Japan, Norway, Sweden, the United States and Yugoslavia, while the following additional countries were represented by observers: Austria, Belgium, Finland, India, The Netherlands and Switzerland.

Following an introductory address on the historical development of marine biological laboratories by Prof. C. M. Yonge, the Conference heard accounts by its members of existing marine laboratories throughout the world. Under the leadership of the official participants, discussions then took place covering the whole field of activities of these laboratories. These included the relations of fundamental and applied research with particular reference to fisheries research, the relationship between marine biological laboratories and the physical aspects of oceanographic research and the role of marine laboratories in graduate and postgraduate education. In addition, the relations between marine laboratiories and universities and government departments or other institutions was discussed.
Much time was naturally spent dealing with questions of financial support, coming as this may from so many sources, although becoming inereasingly dependent on government funds. It was pointed out in later discussions dealing with publication that there are at least a hundred publications devoted wholly or mainly to marine biology (including fisheries), while this number would be more than doubled if journals commonly used for publishing results of marine biological research together with current reports on marine expeditions and surveys were included. The manifold problems of equipment and the technical difficulties of running research aquaria, with the design of research vessels and their gear, occupied much time in the Conference.

Leading naturally from the above topics, which had revealed so much diversity of aim and such varying range of equipment and facilities, the Conference came logically to a consideration of the preparation of an International J)irectory of Marine Laboratories. No existing directory is in any way comprehensive or covers institutions recently established or which have notably increased their facilities since the Second World War. Finally, at this first preliminary international gathering of marine biologists, the need for some permanent organization was discussed. Not only was this considered necessary, but the need for some central organization from which a bulletin of technical information could be circulated was stressed. At the same time, there was felt to be no reason to increase the number of journals dealing with marine biology but rather to reduce these by fusion of the smaller publications, while the advantage of a laboratory distributing its work in the form of collected reprints was stressed.

Much interest was shown in impending develop. ments, which in Europe include the possibility of the foundation of a marine station at Elsinore, together with much expansion and co-operation of work within the four Scandinavian countries. In Germany the laboratory at Heligoland is to be rebuilt, and it is hoped that the Belgian station at Ostend, destroyed in 1940 and now replaced provisionally, will soon bave new buildings. In tropical waters, the activities of the Colonial Fisheries Advisory Committee in establishing laboratories at Freetown, Zanzibar and Singapore were noted with much interest, as were the activities of the University College of the West Indies at Jamaica. The establishment of a second Egyptian marine station near Suez and of laboratories at Curaçao and in Madagascar were reported, together with new Japanese activities in the Bonin Islands. The most obvious gaps in the distribution of marine biological stations appeared to be in parts of the Indian Ocean, notably around Karachi and Ceylon and in the East Indies and also around South America, although there are encouraging activities both in Brazil and in Chile.

After five days of sustained discussion, which all who took part felt fully justified this Conference, the proceedings suitably ended by a visit to the Stazione Zoologica at Naples. There participants and observers were received and entertained by Dr. Reinhard Dohrn and Dr. Peter Dohrn, respectively son and grandson of the founder of this parent institution of all marine laboratories. The great activity of this laboratory, now more than eighty years old, was felt both as a justification of past endeavours and as an encouragement for those of the future.

C. M. Yonge

F. S. Russell 